$\mathbb{T}$ periodica polytechnica

Civil Engineering

$55 / 1(2011) 53 \quad 62$

doi: 10.3311/pp.ci.2011-1.07

web: http://www.pp.bme.hu/ci

(c) Periodica Polytechnica 2011

RESEARCH ARTICLE

\section{The behavior of grids and nets in asphalt pavement}

Kornél Almássy

Received 2010-09-10, revised 2010-09-28, accepted 2010-10-21

\begin{abstract}
In this article, we want to clarify conceptual confusions about grids and nets applying in asphalt pavements structures, define the repairing and -in some cases-damaging effect of grid usage. The biggest question in reinforcement of pavement is the possibility of mixture of grid and net with the asphalt layer below. To observe these attributes we used the method used at bridge lining: slide method. Small and large wheel observations have been made to research track appearances in fortified construction. The lifetime of the construction have been observed by a fatigue method: the standard four point bending method and master curve of the structure. The computer limited number model have been used to prove fatigue results, and with the adequate material model development used at different type of asphalts showed how gross asphalt can be replaced by the nets and grids usage.
\end{abstract}

\section{Keywords}

asphalt layers $\cdot$ grids and nets $\cdot$ stiffness modulus $\cdot$ fatigue life $\cdot$ rut resistance $\cdot$ cohesion

\section{Acknowledgement}

This work is connected to the scientific program of the "Development of quality-oriented and harmonized $R+D+I$ strategy and functional model at BME” project. This project is supported by the New Hungary Development Plan (Project ID: TÁMOP4.2.1/B-09/1/KMR-2010-0002).

\section{Kornél Almássy}

Department of Highway and Railway Engineering, BME, Múegyetem rkp. 3. Budapest, H-1521, Hungary

e-mail: almassy@uvt.bme.hu

\section{Introduction}

Important changes happened lately in reinforcement of asphalt not only in Hungary, but also in Europe. The reinforcement of asphalt has undergone various important changes not only in Hungary, but also throughout Europe. New materials and technology innovation has appeared searching for best practice in methods for avoiding errors in the asphalt pavement. New material and technology help the development of the asphalt pavement quality, in order to reduce the risk of error in the implementation methods.

In the last decade, the era of build in net has commenced. During this period different type and quality of net was built into all asphalt reconstructions all around the country. This work was carried out, without any technological experience and quality control regarding the implementation.

Various distributors advertised that strenghtening nets are the solution to all asphalt pavement construction errors. Recently more and more errors had been registered at pavement with build in net and also new laboratory researches has been made to map all characteristics of build in nets. This paper is only dealing with the asphalt pavement structures, however important to know the usage of grids and nets is very common in semi-felxible and composite pavements.

The purpose of this study is to make a clear understanding about the pros and cons of nets and grids reinforcement in asphalt, and to make a proposal about the implementation methods and it's effect on the environment. At various locations using net is possible and at several others the usage of net is forbidden.

The pictures below show what kind of errors could happen if the net is built in, with the inappropriate method. A wrong placement and not the best type of net had been chosen.

In this paper, we want to clarify conceptual confusions about grids and nets applying in asphalt pavements structures, define the repairing and -in some cases- damaging effect of grid usage. The biggest question in reinforcement of pavement, is the possibility of mixture of grid and net with the asphalt layer below. To observe these attributes we used the three methods: slide method, drag experiment and Leutner Test. Small and large wheel observations have been made to research track appear- 


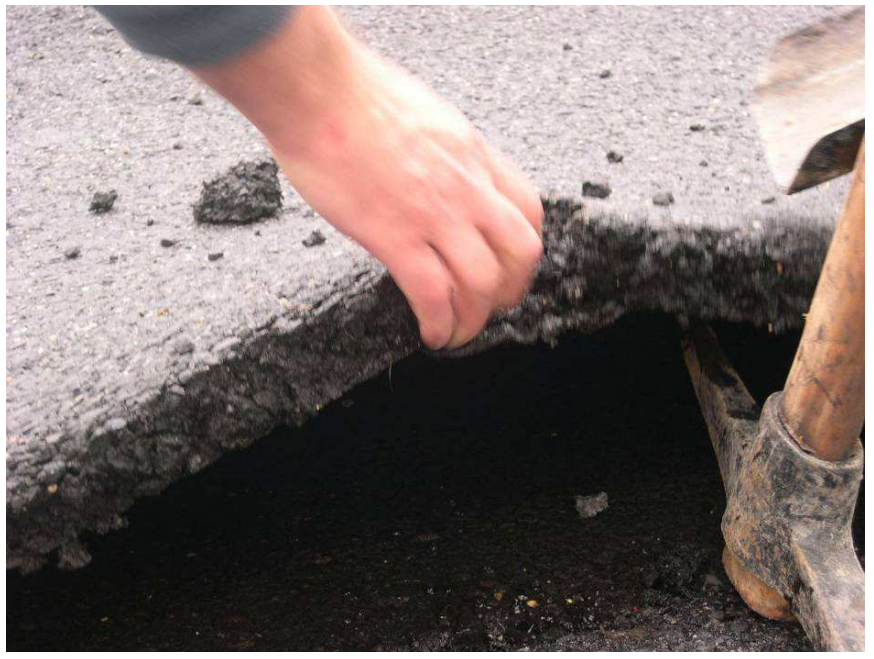

Fig. 1. An extreme example: because of the net usage there is no cohesion between the layers

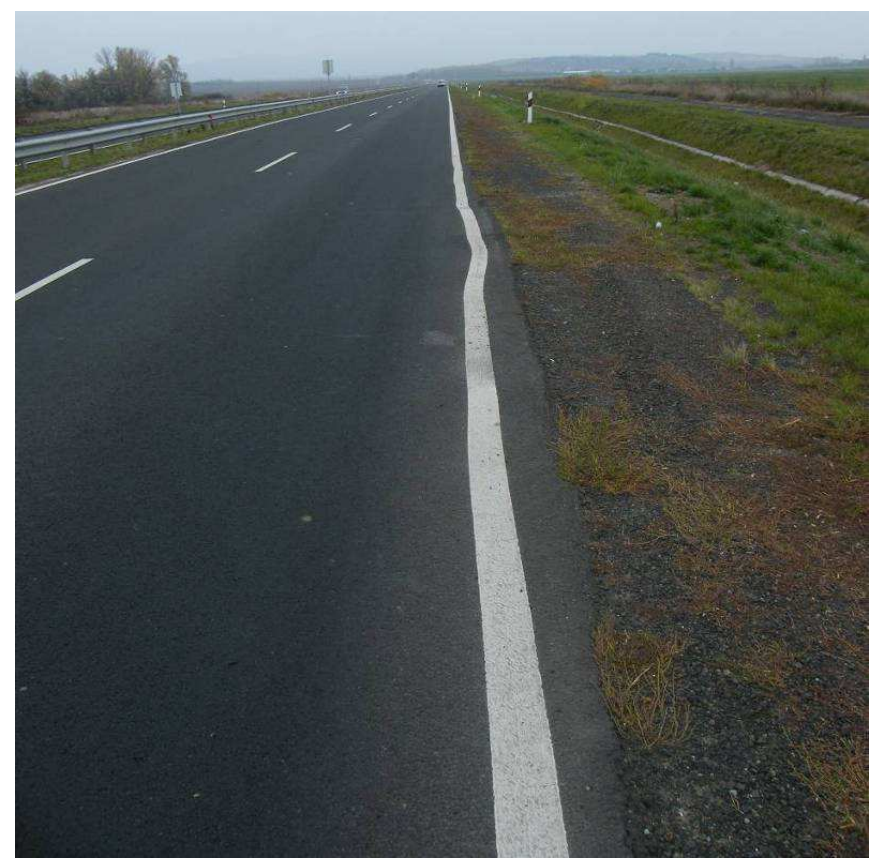

Fig. 2. Because of the build in tissue net, the abrasial layer slipped and a rut has appeared (route 21.)

ances in fortified construction. The lifetime of the construction have been observed by a fatigue method: the standard four point bending method and master curve of the structure. At laboratory work we tested low temperature behavior characteristics of break temperature and tensile test. Applying the well known SHELL-BISAR computer program we analyzed the importance of the stiffness modulus of the grids and the best place of it. The computer limited number model have been used to prove fatigue results, and with the adequate material model development used at different type of asphalts showed how gross asphalt can be replaced by the nets and grids usage.

Because of the shortage of this script, the most important laboratory and computer modeling results of asphalt strengthening researches will be presented.

\section{The applied materials}

The inspections of this scrip had been made between 2003 and 2010. The sampling method has been researched in 2003. The usage of the different asphalt mixtures varied, but we intend to use the common used materials in the research.

In 2003 AB-12 (AB-asphalt concrete) and AB-12/F in 2007 $\mathrm{AB}-11 / \mathrm{F}$ and $\mathrm{mAB}-11 / \mathrm{F}$ for bending AB- 8 materials had been used. In 2008-2010 low quality materials had been used, for better modeling, so in this period AC-11 material has been used for the experiments.

For the tests we used different tensile strength fiberglass, and carbon fibered materials and in some cases iron grids. Before the tests, it is necessary to define the difference between net and grid. Fig. 3 shows a net with bearer material, Fig. 4 shows a grid without bearer material and Fig. 5 represents the iron grid.

Henceforward the net is defined by a net with tissue bearer material and the grid is defined by a net without bearer material, usually coated with sticked binder. [1, 6]

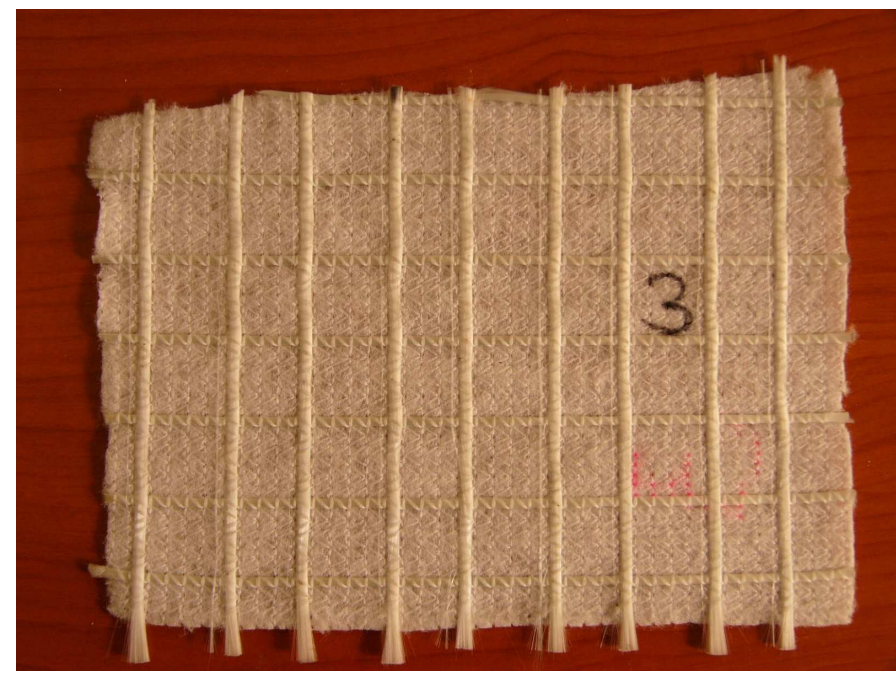

Fig. 3. Net with tissue bearer material (composite material: net and tissue)

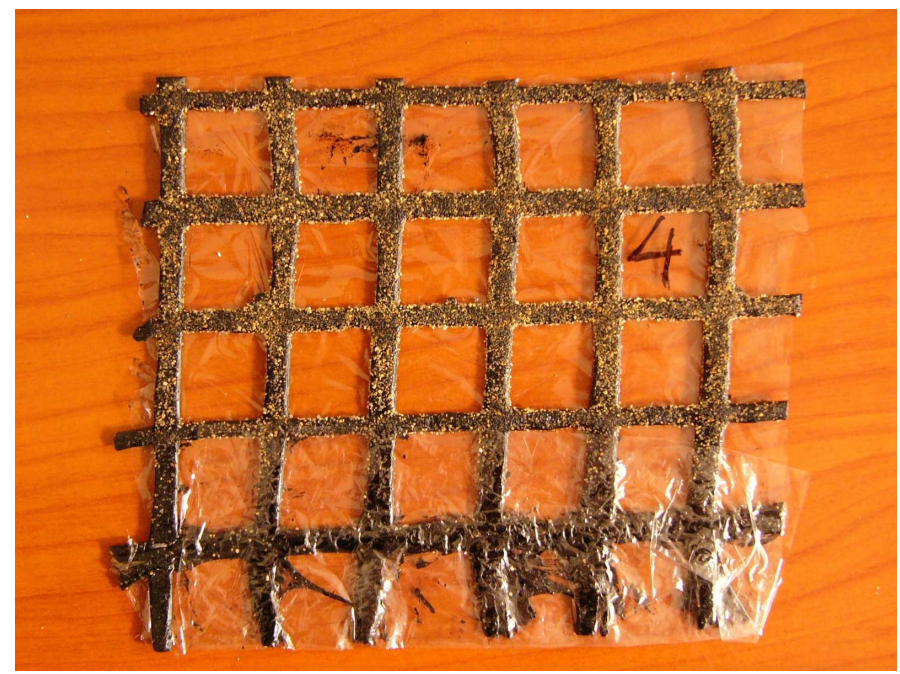

Fig. 4. Grid without bearer material 


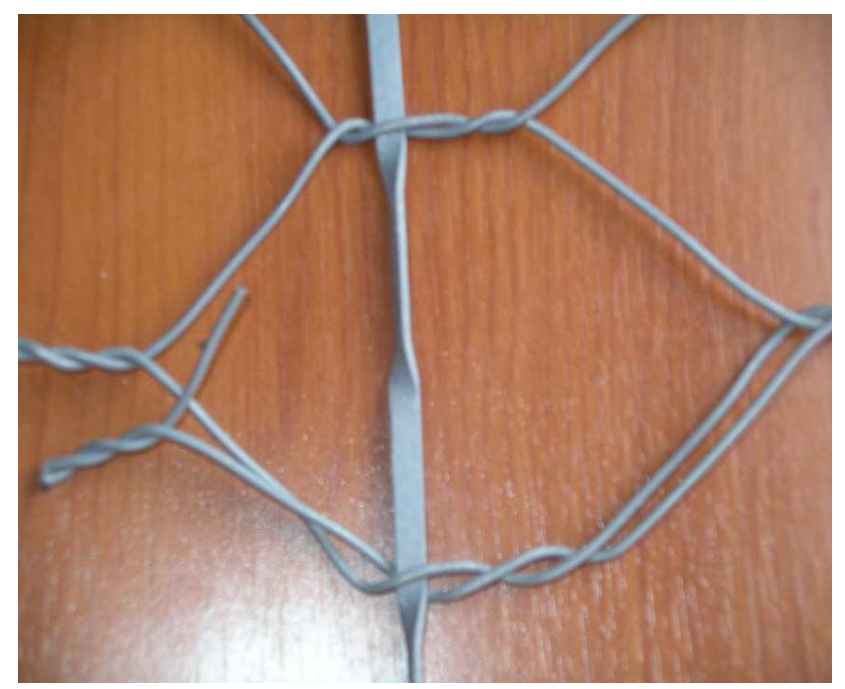

Fig. 5. Iron grid

\section{Mixture test - Cohesion examination}

The asphalt layers mixture, cohesion of two layers are the most important construction requirements. It is highly recommended to assure when a different material is built in between two asphalt layers. The mixture can be examined by three different methods: drag experiment, slipping experiment, and the Leutner method trimming experiment.

Below, the results of drag, slipping experiments and Leutner Test results are presented.

\subsection{Drag test}

The drag test characterize the connection between two layers, the quality of mixture and support with information about the effect of perpendicular cohesive duration to the layer.

Multiple drag experiments has been made recently, among these, laboratory experiments have been made with sample materials and also already constructed pavement structures in use had been tested.

During the tests the sample materials without strengthening had been above the $1.0 \mathrm{~N} / \mathrm{mm} 2$ level, but and the tissued nets did not reached this requirement, the grid usage however almost reached the level and always ranked better then the tissued sample materials.

The sample from M1 highway could not have been tested because the layers are separated which is caused by the bad mixture. [2,3]

\subsection{Slipping test}

The mixture and the non mixture is defined by the so called slipping test, which is used for bridge lining and pavement stickiness level measuring.

The scope of the test is to define the maximum of trim power which appears between two layer at parallel usage.

This experiment is not like the well known layer limit trimming experiment the difference is that in this technique the layer is under pressure. Usually bridge lining researches are made in base of this method. [3, 4]

In 2004 we firstly finished experiments with tissue bearer net and grid fortified sample materials. The net sample material trim durability grades always stayed behind not only the reference sample material but also the grid fortified one. The table below shows the results of 2008-2009 experiments:

At the end of 2008 and the beginning of 2009 we elaborated more slipping experiments. These results appears in Tab. 1 Based on the experiments of 2008 that all of tissue bearer material works as a dividing layer and has bad effects for mixture and for trimming resistance. The asphalt grids with non bearer material, produced the same results as the sample materials without net.

\subsection{Leutner test}

The Leutner test is the worldwide most common full test method, to analyze cohesion between two asphalt layer or the grid and the layer. This is a shearing test where the shearing is perpendicular with the layer. The trends of the Leutner test are similar with the above mentioned slipping and drag experiments results. The asphalt specimen with non bearer material and the iron grid produced much more shearing strength results, than the tissued net specimens.

\subsection{Summarized the cohesion examination}

According to the mixture experiments (drags, slipping and Leutner shearing tests) we justified that applying grids or nets, effectiveness of the cohesion is decreased significantly. The tissue bearer materials produced the worst cohesion value because of the dividing effect of the nets. The applied asphalt grids with non bearer material can produce $60-90 \%$ of the cohesion values of the asphalt specimens without any strengthening material. In the case of the tissue bearer material that number is changed between $20-40 \%$. The next picture shows the results of the drags and slipping test. In this case only the same asphalt and grid materials were compared, thats why can see merely the drags and slipping test results.

We analyzed the difference of the results within the separate experiments the grids strengthened specimens. We represented in the below image that specimens which had at least two results from two different test method.

\section{Wheel tracking tests}

A cored or laboratory compacted slab of hot mix asphalt is subjected to repeated passes of a loaded wheel while the resultant rut depth is monitored. Wheel tracking is popular because it is more simulative than other laboratory methods of assessing resistance to permanent deformation and results have been shown to correlate well with in-service pavement rutting. Wheel tracking device consisting of a loaded wheel that bears on a specimen held on a moving table. The table oscillates beneath 
Tab. 1. Slipping experiment from 2008-2009

\begin{tabular}{cccc}
\hline \multicolumn{1}{c}{ Sample material } & Trim durability $\left(\mathrm{N} / \mathrm{mm}^{2}\right)$ & Slip at max. force & Trim modulus measures $\left(\mathrm{N} / \mathrm{mm}^{2}\right)$ \\
\hline in $\mathbf{2 0 0 8}$ & & & \\
\hline „A"sign, without bearing material, fiberglass asphalt grid & $0,92 \mathrm{~N} / \mathrm{mm}^{2}$ & $18,2 \%$ & $50,5 \mathrm{~N} / \mathrm{mm}^{2}$ \\
\hline „B" sign, without bearing material, carbonfiber asphalt grid & $0,87 \mathrm{~N} / \mathrm{mm}^{2}$ & $15,0 \%$ & $59,03 \mathrm{~N} / \mathrm{mm}^{2}$ \\
\hline "C" sign tissued, fiberglass asphalt grid & $0,60 \mathrm{~N} / \mathrm{mm}^{2}$ & $31,3 \%$ & $19,19 \mathrm{~N} / \mathrm{mm}^{2}$ \\
\hline „D” sign tissue, carbonfiber asphlat net & $0,52 \mathrm{~N} / \mathrm{mm}^{2}$ & $40,6 \%$ & $12,85 \mathrm{~N} / \mathrm{mm}^{2}$ \\
\hline Without net - sample & $0,88 \mathrm{~N} / \mathrm{mm}^{2}$ & $18,4 \%$ & $48,69 \mathrm{~N} / \mathrm{mm}^{2}$ \\
\hline in 2009 & & & $36,31 \mathrm{~N} / \mathrm{mm}^{2}$ \\
\hline dense doublewire asphalt grid (GlasGrid 8501$)$ & $0,83 \mathrm{~N} / \mathrm{mm}^{2}$ & $23,5 \%$ & $42,71 \mathrm{~N} / \mathrm{mm}^{2}$ \\
\hline Loose doublewire asphaltgrid (GlasGrid 8511$)$ & $1,21 \mathrm{~N} / \mathrm{mm}^{2}$ & $24,9 \%$ & $41,16 \mathrm{~N} / \mathrm{mm}^{2}$ \\
\hline Irongrid & $1,10 \mathrm{~N} / \mathrm{mm}^{2}$ & $21,9 \%$ & $55,69 \mathrm{~N} / \mathrm{mm}^{2}$ \\
\hline No grid - reference & $1,25 \mathrm{~N} / \mathrm{mm}^{2}$ & $16 \%$ & \\
\hline
\end{tabular}

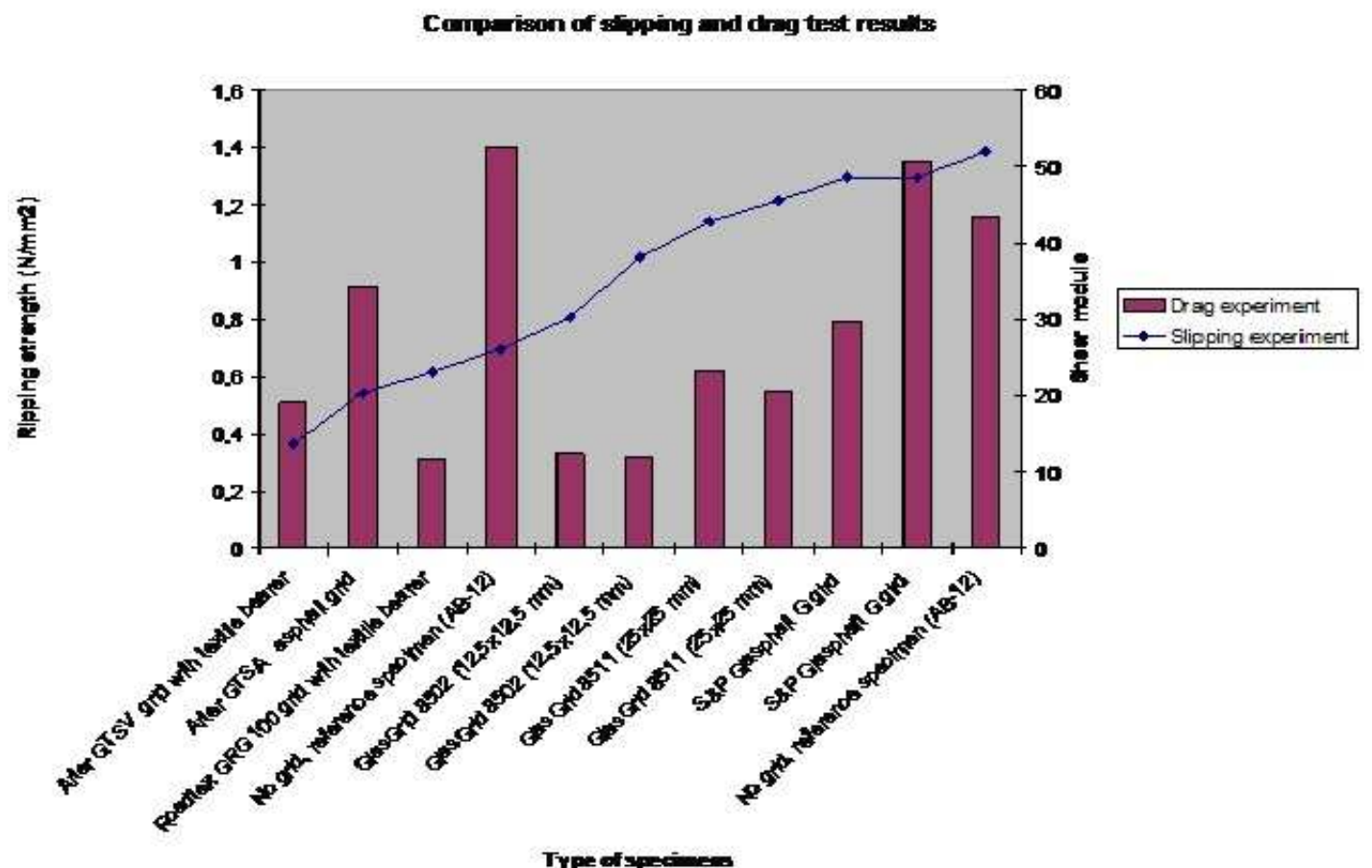

Fig. 6. Comparison of slipping and drag test results

the loaded wheel and a displacement measuring device is provided that measures the vertical depth of the rut as it develops. [13]

The wheel shall be fitted with a solid rubber tyre of outside diameter $200 \mathrm{~mm}$. The tyre shall be of rectangular section $50 \pm$ $1 \mathrm{~mm}$ wide and $10 \mathrm{~mm}$ to $13 \mathrm{~mm}$ thick. The rubber shall have a hardness number of $80 \pm 5$ IRHD units. The wheel load, under standard conditions, shall be $P=0,4 \mathrm{~N} / \mathrm{mm}^{2}$. After $\mathrm{N}=8340$ wheel tracking (at big wheel test $\mathrm{N}=60000$ ) the apparatus measure the specific extension $(\%)$ of the structures. The wheel tracker shall be fitted with a temperature controlled cabinet with a temperature range of $30{ }^{\circ} \mathrm{C}$ to $60{ }^{\circ} \mathrm{C} \pm 1{ }^{\circ} \mathrm{C}$.

\subsection{Wheel tracking test with different type of grids}

Rut appearance is the most important characteristics of asphalt pavements, which reflects the hot resistance level. The aim of strengthening with nets and grids is to reach a resistance for rut appearance and that the intensity of tracks. Recent years we made tests to prove these concepts, but the results reflected a wide variety of measures, but the sample materials with net showed better rut appearance characteristics, than the non net material results, the best results came from the grids without bearing material. Last year we experimented big and small wheel rut appearance tests in AC-11 asphalt mixture, tissued net, grids without bearing material, and iron net. The following table shows the results of small wheel rut appearance test. The results of different type of net and grid are so close to each other, but 


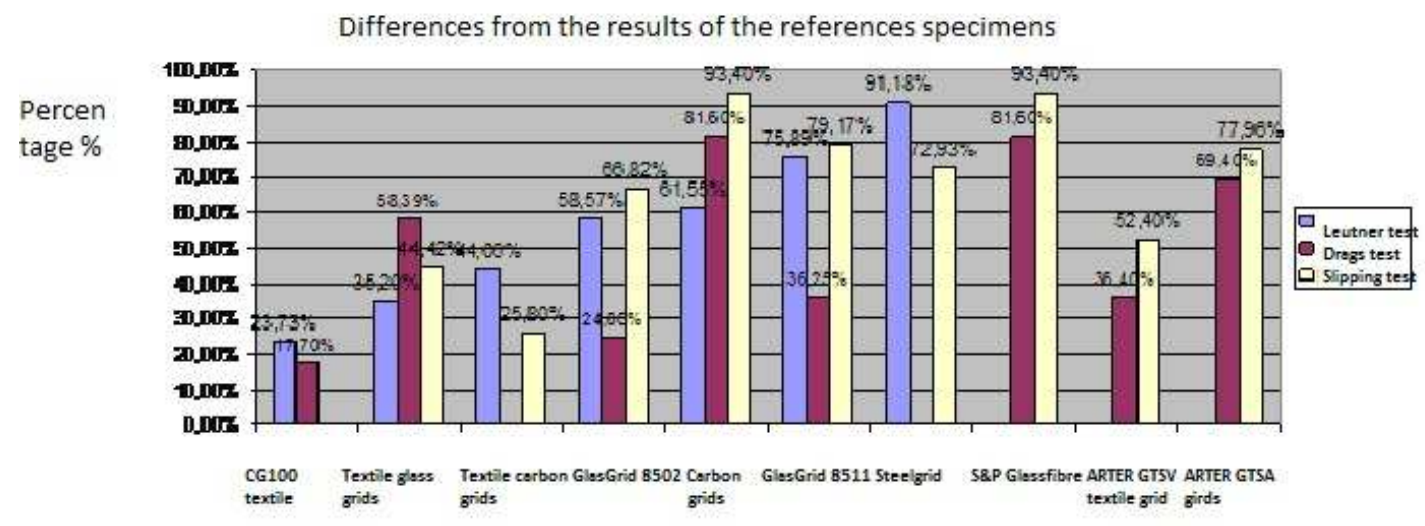

Type of the specimens

Fig. 7. Diffreneces from the results of the references specimens

the grids reach a better rut appearance results, comparing to the sample material the strength of nets is clearly visible. [5, 7, 10]

Tab. 2. Wheel tracking experiment results from march 2009.

\begin{tabular}{ccc}
\hline Type of net & Net track $\varepsilon(\%)$ & Net track $\varepsilon(\%)$ average \\
\hline tissued net & 2,82 & 2,68 \\
tissued net & 2,54 & \\
\hline $100 / 200$ dense tissued grid & 3,09 & 2,65 \\
$100 / 200$ dense tissued grid & 2,21 & \\
\hline $100 / 200$ dense tissued grid & 2,11 & 2,22 \\
$100 / 200$ dense tissued grid & 2,33 & \\
\hline $100 / 200$ dense tissued grid & 2,03 & 2,04 \\
$100 / 200$ dense tissued grid & 2,04 & 2,16 \\
\hline $100 / 100$ loose tissued grid & 2,32 & 2,11 \\
$100 / 100$ loose tissued grid & 2 & \\
\hline $100 / 100$ loose tissued grid & 2,03 & 2,55 \\
$100 / 100$ loose tissued grid & 2,2 & \\
\hline $100 / 100$ loose tissued grid & 2,86 & 4,25 \\
$100 / 100$ loose tissued grid & 2,25 & 4,43 \\
\hline Without net- reference & 4,03 & \\
Without net- reference & 4,48 & \\
\hline Without net- reference & 4,29 & \\
Without net- reference & 4,57 & \\
\hline
\end{tabular}

Because of the wide variety of the results and to reach better and reliable result for rut appearance we also made big wheel test respecting the MSZ EN 12697-22 standards. The results showed same situation as we had realized at the previous ,,small wheel" test. The test has been made with a $6 \mathrm{~cm}$ AC-22 mixture with net, covered by $4 \mathrm{~cm}$ AC-11 wearing course layer.

Following type of nets and grids were used for the test:

- S\&P Glasphalt G fiber glass asphalt grid (without bearer material)

- Gradex Alpha Mesh GR-G (tissue, fiberglass)
- GeoGrid Bitutex GMC 50/50 (two layer tissued)

- Bekaert Bitufort (iron grid)

- Sample without a net

- Glass Grid CG100 (25 mm x 25 mm grid) tissued net

- Glass Grid 8502 dense tissued (25 mm x $25 \mathrm{~mm}$ grid) asphalt grid (without bearer material)

- Glass Grid 8511 loose tissued (12,5 mm x 12,5 mm grid) asphalt grid (without bearer material)

The results of the 2008 test are showed on Fig. 8. It is surprising that S\&P grid without bearing material produced the worst results, which is possible because of a construction problem with one of the tests. The other nets produced a better result as the sample material.

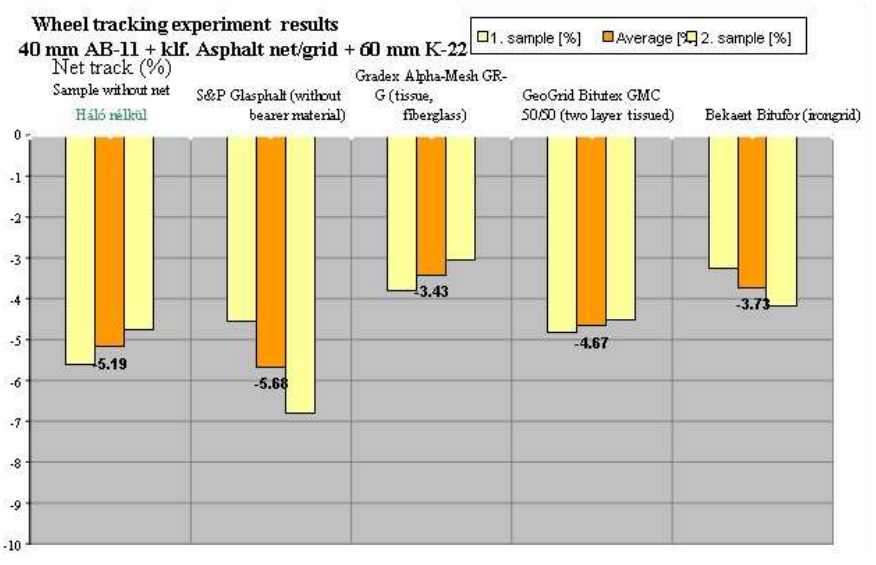

Fig. 8. The results of rut appearance tests in 2008

\subsection{Contraction of the rutting test}

After the long years examination observations showed that using asphalt grids in poor quality mixture can improve the rutting behavior of the structure. The results can be $40 \%$ less than the 


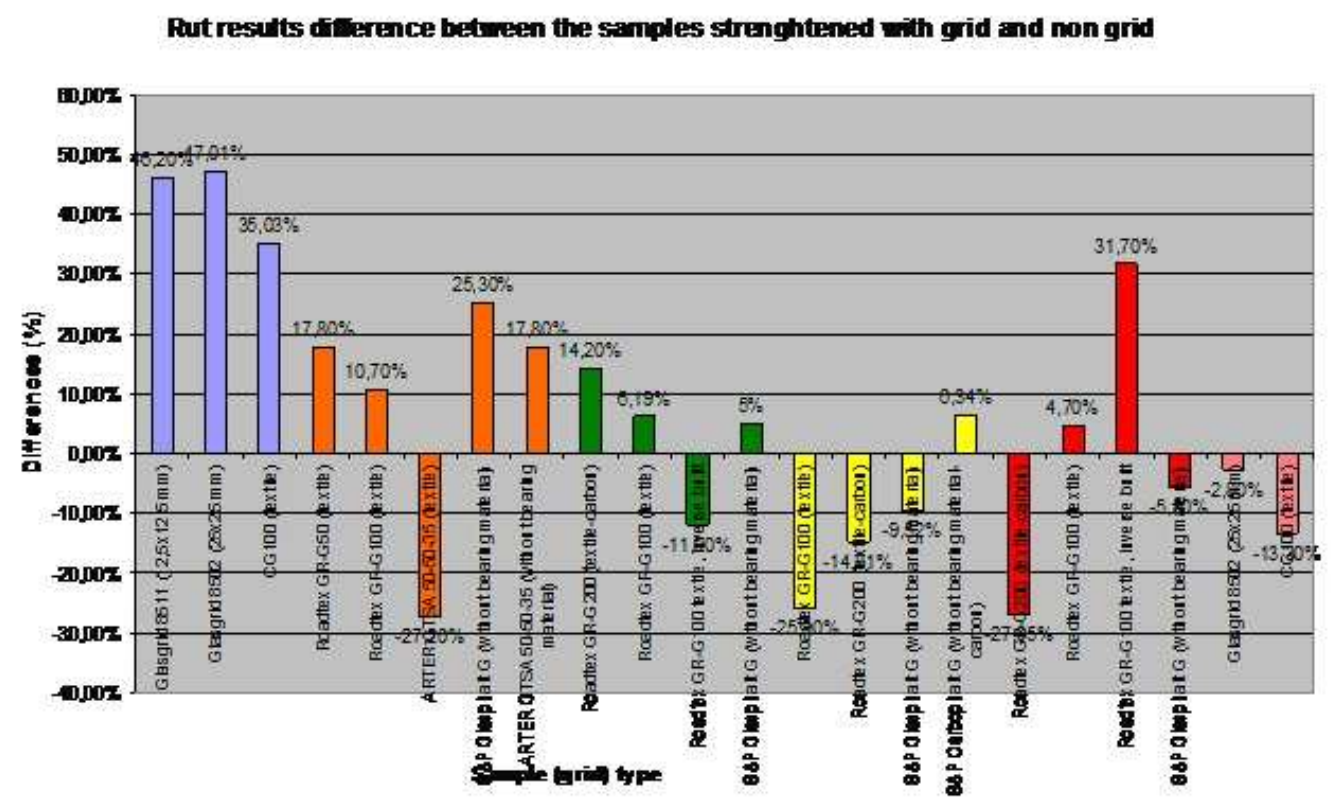

Fig. 9. Rut results difference between the samples strengthened with grids and non grids

reference, unreinforced (without grid) specimens values. Otherwise at the case of the mixture with better permanent deformation instinct - in Hungary signed F type mixture - the change is not standard.

We also proved that applying the tissued net in asphalt reinforcement could produce worse results than the asphalt grids without a bearing material, we get less ruting results in that case. It can be see in the under mentioned picture. (The tissued nets results are tinted with different colors, but we did not use different color for the grids without bearing material.)

\section{Fatigue life - 4-point bending beam test}

To characterize nets, grids result, endurance test has to be made respecting MSZ EN 12697-24:2005 standards. This standard describe the properties of asphalt mixture fatigue, we have chosen the four point bending technique as testing method. [8] The experiments are made with controlled strain driven mode or controlled stress mode in $10^{\circ} \mathrm{C}, 10 \mathrm{hz}$ frequency. Fatigue is defined by the decrease of durability of the material because of multiple endurance tests, compared to the first endurance test. The criteria of breakage is defined by the (in case of constant shift) the endurance test number $\mathrm{N}_{f} / 50$, in witch the complex endurance rate fall to the half. For measuring the experiment, we observe de rate of complex endurance, witch is the rate of 100 endurance test repeat [12].

In the last five years number of bending beam tests have been made, but these test are incomparable with each other, because they are made in different years and with different asphalt mixture materials. (The sample material of the year 2007 was AB-8 type asphalt, in 2004 AB-12, but in this year was also incomparable because of the different asphalt mixture.) The table below show the difference of net and without net sample material results, and show the current tendencies.

The results show clearly that the tests made without net pro-

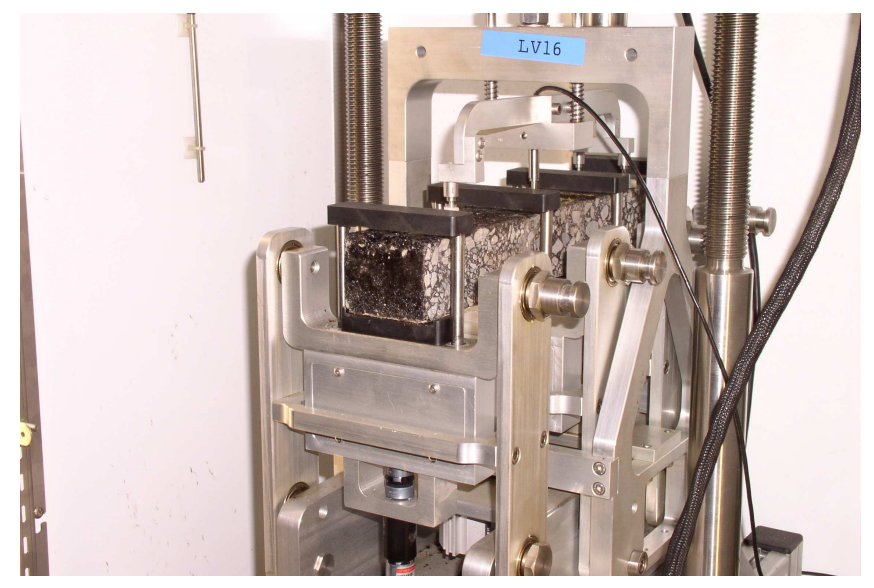

Fig. 11. Apparatus for the 4 point bending beam test

duced less stress and strain, and the fatigue lines reflect that net fortified materials durability and lifetime is raised. (5\% to $25 \%$ )

The result of the may 2004 test shows that tissued nets raise the results with only a few percent, but in other cases a serious $15 \%$ results appear. It is clearly visible that the nets without bearing materials are the most resistance to stress and strain. (The 2007 pavement sticking grid worse results are caused by non appropriate construction technology) (1), (2)

\section{Master Curve}

The master curve is an appropriate tool to describe the behavior of the different asphalt mixtures. Different shift coefficients were used in this calculation. According to a Dutch method, the slope of the master curve determines the fatigue characteristic of the asphalt mixture. As we know, this was the first time when the master curve had been determined for grid/net strengthened asphalt specimens.

We can analyze the attitude of the asphalt at very special time and frequency range using master curve method and in this ex- 


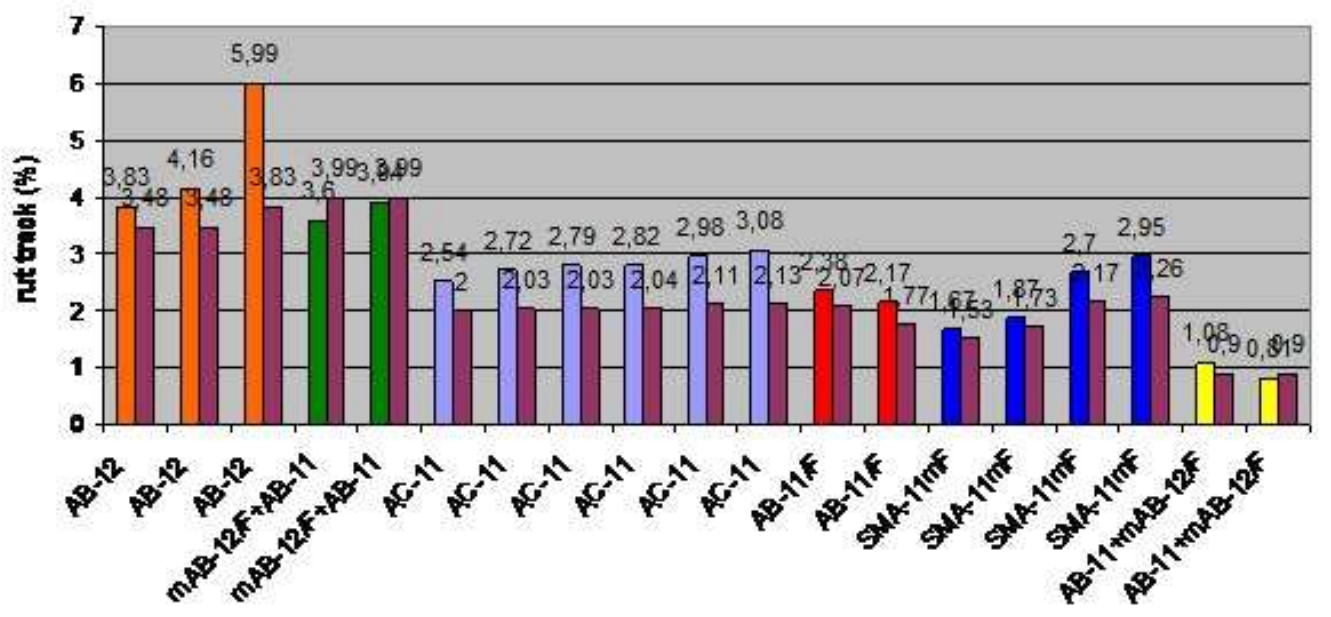

Smiple trpes

Fig. 10. Comparison of the rut result tissued bearing specimen againts the specimen strengthened grids without bearing material

Tab. 3. Summarized table of bending experiments (1), (2)

\begin{tabular}{|c|c|c|c|}
\hline Type of net & Result: strain or stress & Difference of without net results & Date of experiment \\
\hline without net & $142 \mu$ strain & - & 2007. may \\
\hline 3. nr. Gradex tissued, fiberglass net & $167 \mu$ strain & $17,6 \%$ & 2007. may \\
\hline 4. nr. S\&P fiberglass grid, sticked with bitumen emulsion & $150 \mu$ strain & $5,6 \%$ & 2007. may \\
\hline 4. $n r$. S\&P fiberglass grid, sticked with hot air blower & $170 \mu$ strain & $19,7 \%$ & 2007. may \\
\hline without net & $1,29 \mathrm{~N} / \mathrm{mm}^{2}$ & - & 2004. may \\
\hline Roadtex GR-G50 & $1,31 \mathrm{~N} / \mathrm{mm}^{2}$ & $1,5 \%$ & 2004. may \\
\hline Roadtex GR-G100 & $1,35 \mathrm{~N} / \mathrm{mm}^{2}$ & $4,6 \%$ & 2004. may \\
\hline Roadtex GR-G200 & $1,46 \mathrm{~N} / \mathrm{mm}^{2}$ & $13,1 \%$ & 2004. may \\
\hline S\&P Glasphalt G & $1,55 \mathrm{~N} / \mathrm{mm}^{2}$ & $20,1 \%$ & 2004. may \\
\hline S\&P Carbophalt $G$ & $1,56 \mathrm{~N} / \mathrm{mm}^{2}$ & $20,9 \%$ & 2004. may \\
\hline without net & $1,36 \mathrm{~N} / \mathrm{mm}^{2}$ & - & 2004. may \\
\hline ARTER GTSA (without bearer material) & $1,96 \mathrm{~N} / \mathrm{mm}^{2}$ & $44,1 \%$ & 2004. december \\
\hline ARTER GTSV (tissued) & $1,68 \mathrm{~N} / \mathrm{mm}^{2}$ & $23,5 \%$ & 2004. december \\
\hline Without net & $1,34 \mathrm{~N} / \mathrm{mm}^{2}$ & - & 2008. march \\
\hline 7. nr. Carbophalt G type grid, without bearer material & $1,56 \mathrm{~N} / \mathrm{mm}^{2}$ & $16,4 \%$ & 2008. march \\
\hline 2. nr. Gradex tissued carbon net & $1,28 \mathrm{~N} / \mathrm{mm}^{2}$ & $-4,4 \%$ & 2008. march \\
\hline
\end{tabular}

treme condition we could not solve without it.

Determination of the master curve we was curious the stiffness differences of the grid reinforced and unreinforced specimen's value. We would like to know when starts to work the grid, to set forth positive impact. The stiffness of the asphalt structure increase at the higher frequency range for the benefit of the reinforced specimen. At medium frequency level the grid reinforced specimen has got same stiffness value like the unreinforced sample.

Fig. 12 shows the master curves of the strengthened and nor- mal specimens (without grids).

\section{Cold behavior}

At asphalt testing the cold side of bearing is such is so important than the warm attitude of the asphalt. [9] Above all the grids are advertised for the brand-switcher as a materials which are adopted to the the cold thermal stress. We could justify that after hampered strain test there are no differences between the grid strengthened and non grid asphalt structure at the cold cracking temperature. The hampered strain test is not capable for analyzing the grid strengthening, because the length of the grid is 


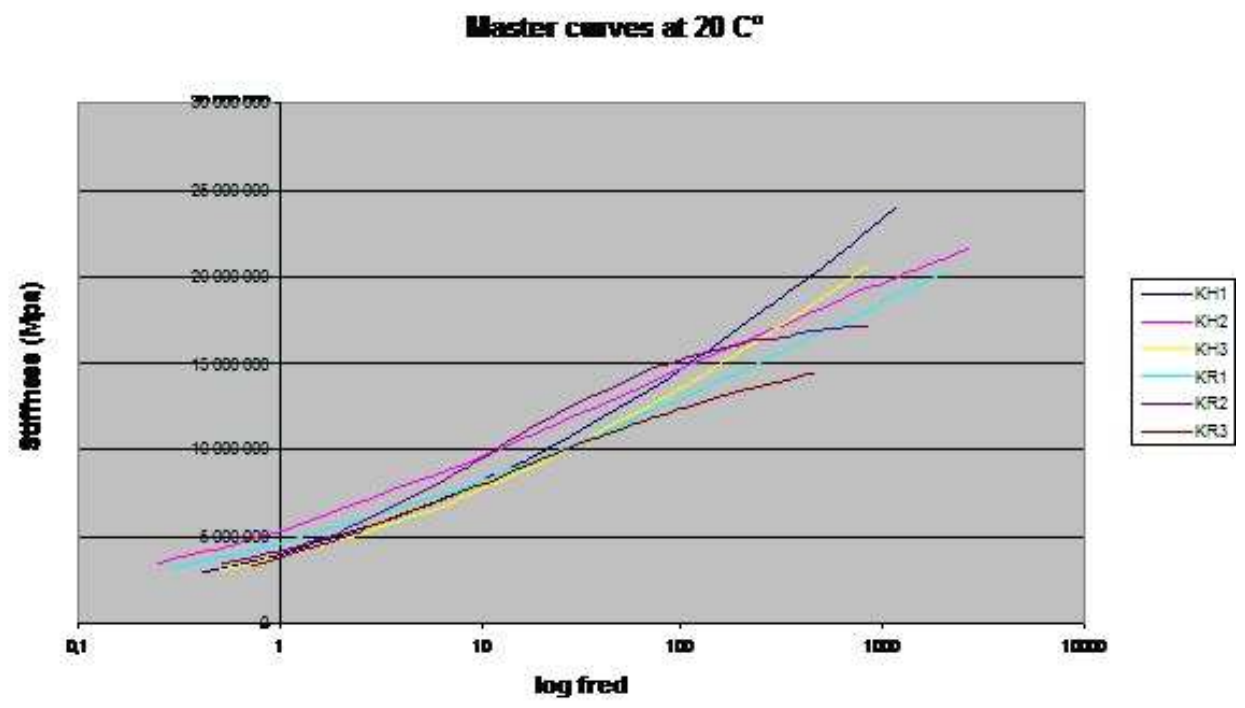

Fig. 12. Master curves of the non grid and grid strengthened specimens (KH: grid, KR: reference)

not changing therefore is not able to take over stress from the deformed asphalt.

After the hampered strain test we tryed to determine in an other way the cold behaviour of the grid reinforced samples. In the so called "clear" tensile test we haul the sample with permanent speed at temperature $-10^{\circ} \mathrm{C}$. Contrarily after at the $-10{ }^{\circ} \mathrm{C}$ made tensile test we can say that the built in grid between the two asphalt layers improve for more than 11-19\% the tensile strength value of the structure. The next image shows the result.

\section{BISAR computer program examination}

The Dutch Shell-BISAR computer program is a bitumen stress analysis in road pavement, which is excellent for examining stress, strain and displacement situation of any point of the pavement structure. Therefore we could easily determine some interesting permanent question in line with using asphalt grids.

We justified with BISAR testing, that the asphalt grid only starts to work when the stiffness of the above asphalt layer increase because of carrying capacity defect and cracks. In this case it has been justified that the grid is suitable for crack prevention, on the other hand at the less stiff asphalt structure the grid has been starting to work at the beginning. Therefore is effective to apply grid with higher stiffness modulus and smaller strain behavior.

We verified that below the binder course, at the case of $13 \mathrm{~cm}$ deep grid reinforced structure would be the smallest the measured strain at the bottom of the 2. and 3. layer contrary of grid situated 4, 5, $6 \mathrm{~cm}$ deepness. Depending of the structure condition and failure the strain would be $26-43 \%$ less if we build in the grid below the binding course. [11]

\section{Finite element modeling}

The associates of Department of Structural Engineering and the Department of Highway and Railway Engineering have made an experiment parametric to the asphalt pavement limited modeling. The task aimed to define the effect of different rigid- ity nets to asphalt stretching. For all layer construction and net pairing we wanted to reach equivalent asphalt thickness. where we can reach without net low asphalt layer stretching, and we wanted to observe if the usage of net or the grid is able to reach thinner asphalt layer thickness.

The experiment aimed to define the shape of shifting and the asphalt reinforcement net usage equivalent thickness definitions showed different layers in the pavement structure. The most complex pavement is shown on Fig. ??.

In this model the upper four layer is asphalt, the next is subbase, and the lowest is sub-grade. The asphalt and the base layers thickness is changing during the tests, but the sub-grade thickness is $3000 \mathrm{~mm}$ in all tests.

The limited component model is the 2 dimensional segment of a sector model. Between the different material layers we can find contact lines where the limited component slipping and derivation is allowed and the layers mix in case of pressure. Total slipping is supposed to be between the contact lines.

In case of the asphalt strengthening net equivalent thickness definition a net is placed below the lowest asphalt layer which is $0.5 \mathrm{~mm}$ thick. ANSYS common limited component modeling software was used for asphalt pavement modeling.

Both of the model structures were based on the same limited component types. The pavement components (asphalt, pavement bases, sub-grade) modeling was made with ANSYS PLANE 42 plane shape shifting state face, which has 4 junction, and all the junctions have 2 free levels.

We defined for the modeling the $3^{*} 12$ type different asphalt pavement characteristics (thickness, rigidity, Poisson component) with 3 different rigidity modulus in the same temperature, and 12 different layer structure.

Utilizing net in modeling results in most cases only a few millimeter asphalt decrease, more than a centimeter is allowed with 10-2000 MPa stiffness nets and $30-50^{\circ} \mathrm{C}$ pavement structure was reached. The question is that if $0,5 \mathrm{~mm}$ thickness covered net is capable of getting 10000 or 20000 MPa stiffness modulus. (5) 


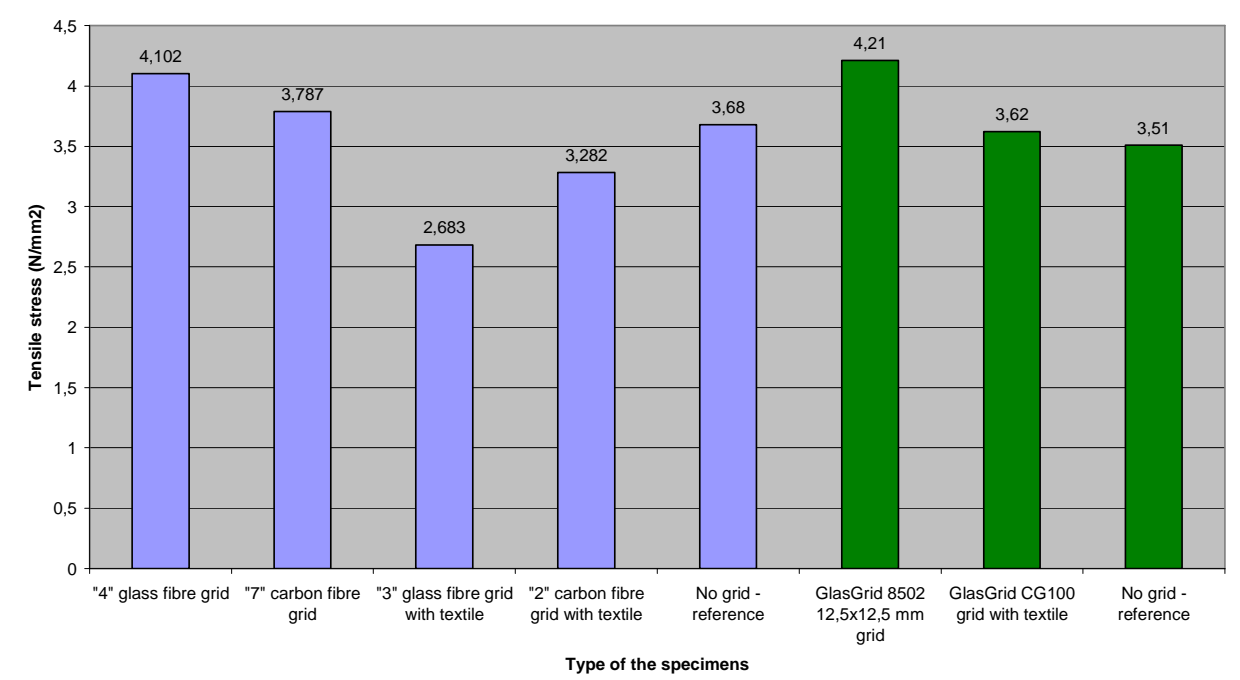

Fig. 13. Results of the tensile test at $-10{ }^{\circ} \mathrm{C}$

Horizontal strain at $0,13 \mathrm{~cm}$ depth, with using grids in different deepness (Strain $\mathbf{x x}$ )

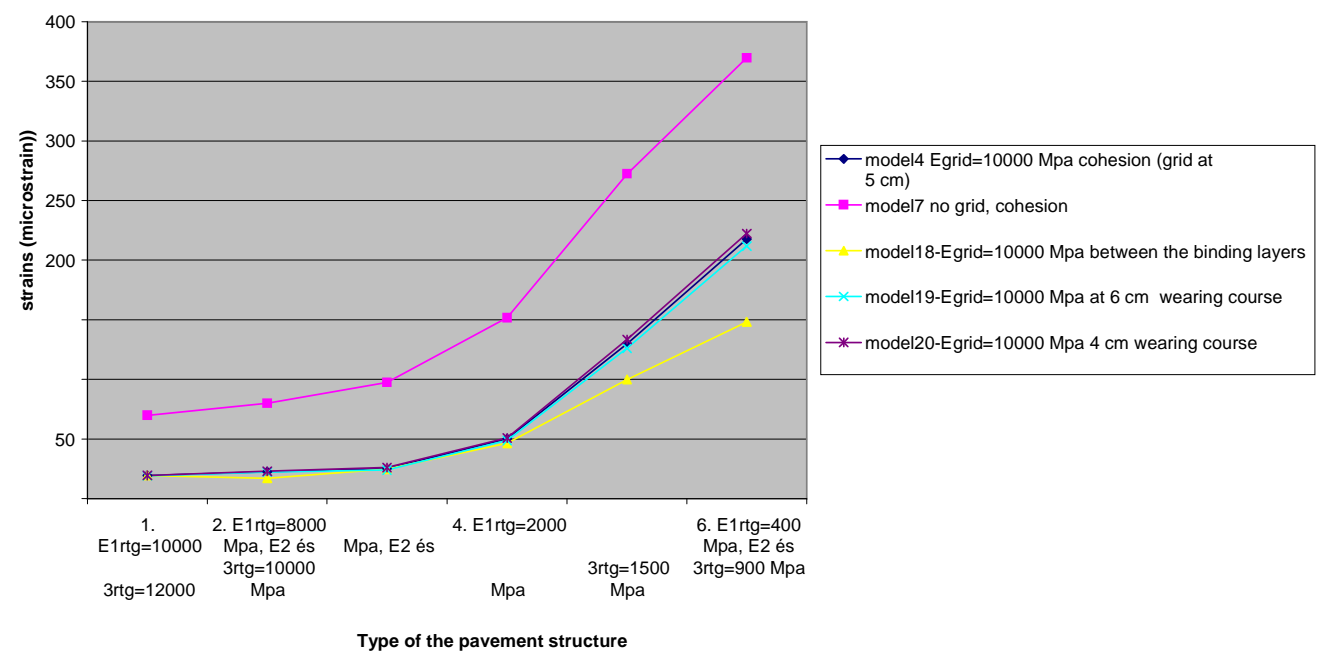

Fig. 14. Horizontal strain at $0,224 \mathrm{~mm}$ depth with using grids in different deepness

\section{Conclusions}

- We justified that applying grids or nets, effectiveness of the cohesion is decreased significantly. The tissue bearer materials produced the worst cohesion value because of the dividing effect of the nets. The applied asphalt grids with non bearer material can produce $60-90 \%$ of the cohesion values of the asphalt specimens without any strengthening material. In the case of the tissue bearer material that number is changed between $20-40 \%$.

- Wheel tracking examination observations showed that using asphalt grids in poor quality mixture can improve the rutting behavior of the structure. The results can be $40 \%$ less than the reference, unreinforced (without grid) specimens values. Otherwise at the case of the mixture with better permanent deformation instinct - in Hungary signed F type mixture the change is not standard. We also proved that applying the tissued net in asphalt reinforcement could produce worse re- sults than the asphalt grids without a bearing material, we get less ruting results in that case.

- The 4 points bending beam test results show clearly that the tests made without net produced less stress and strain, and the fatigue lines reflect that net fortified materials durability and lifetime is raised. (5\% to $25 \%$ )

- With the creation of the master curves we could confirm that the stiffness of the asphalt structure increase at the higher frequency range for the benefit of the reinforced specimen. At medium frequency level the grid reinforced specimen has got same stiffness value like the unreinforced sample.

- We justified with BISAR testing, that the asphalt grid only starts to work when the stiffness of the above asphalt layer increase because of carrying capacity defect and cracks. In this case it has been justified that the grid is suitable for crack prevention, on the other hand at the less stiff asphalt structure 
the grid has been starting to work at the beginning. Therefore is effective to apply grid with higher stiffness modulus and smaller strain behavior. We verified also that below the binder course, at the case of $13 \mathrm{~cm}$ deep grid reinforced structure would be the smallest the measured strain at the bottom of the 2 . and 3. layer contrary of grid situated $4,5,6 \mathrm{~cm}$ deepness.

- The finite element modeling shows that grids can be considered as replacer if there stiffness is bigger than $10.000 \mathrm{MPa}$. The modeling showed that fortifying effects came in above $30-50^{\circ} \mathrm{C}$, which shows that net should reach a better heat resistance for asphalt pavement.

\section{References}

1 Almássy K, Aszfalterôsítő hálók szerepe - Valóban segítség?, 2008. HAPA Fiatal mérnökök fóruma.

2 Almássy K, Ambrus K, Kárpáti L, Új technológiák, termékrendszerek bemutatása: Aszfaltrácsok alkalmazási tapasztalatai, 2009. Magyar Közút Zrt. Oktatási Osztály Út és hídépítési múszaki elôírások és alkalmazási tapasztalataik (MEP5-8) tanfolyama.

3 Almássy K, Ambrus K, Bocz P, Fi I, Aszfalthálók útépítési alkalmazásai, Közúti és mélyépítési szemle 55 (2005), no. 4, 30-36.

4 Almássy K, Ambrus K, Fi I, Frigyes Kovácsházy, Pozitív hatások - Aszfalthálók viselkedésének vizsgálata, 2004. Mélyépítő Tükörkép Magazin.

5 Almássy K, Joó A, Special materials in the road building - Grids and netts application terms for improving the pavement structures, Building Materials 61 (2009), no. 2, 55-59.

6 Almássy K, Examination of Mechanical Properties in Unbound Road Bases, Periodica Polytechnica Civil Engineering 46 (2002), no. 1, 53-69.

7 Devecseri G, Effect of heating on the physical properties of asphalt aggregates, Periodica Polytechnica Civil Engineering 54 (2010), no. 1, 53-60, DOI 10.3311/pp.ci.2010-1.06.

8 Bocz $\mathbf{P}$, The effect of stiffness and duration parameters to the service life of the pavement structure, Periodica Polytechnica Civil Engineering 53 (2009), no. 1, 35-41, DOI 10.3311/pp.ci.2009-1.05.

9 Pethö L, Influence of temperature distribution on the design of pavement structures, Periodica Polytechnica Civil Engineering 52 (2008), no. 1, 4553, DOI 10.3311/pp.ci.2008-1.07.

10 Almássy K, Geiger A, Gergó P, Using possibilities of rubber bitumen in road building, Pollack Periodica 5 (2010), no. 1, 53-63, DOI 10.1556/Pollack.5.2010.1.3.

11 Moussa G K M, The optimum location of geotextile reinforcement in asphalt layers, 2003. Alexandria Engineering Journal.

12 de Bondt A H, Anti-Reflective Cracking Design of Asphalic Overlays, Technical University of Delft, TU Delft, Delft, Netherlands, 1999. PhD thesis.

13 Rolandas O, Rutting associated with shear deformations on asphalt concrete road pavements reduction by means of geosynthetic material, Vilnius Gediminas Technical University, Vilnius Gediminas Technical University, Vilnius, Lithuania, 2006. PhD thesis. 